\title{
Statistical Analysis of the Activities of Individual Entrepreneurs in the Regions of Russia
}

\author{
Angelica Vasilieva* \\ Department of Economics and Management of the organization, Amur State University, \\ Blagoveshchensk, Russia
}

\begin{abstract}
The spread of coronavirus infection caused significant damage to enterprises in the region. The least protected business entities individual entrepreneurs - suffered the most. The introduction of the selfisolation regime led to a decrease in demand for goods and services of individual entrepreneurs, an increase in business costs, and the accumulation of debts to landlords and creditors. Having fallen into a difficult economic situation, many individual entrepreneurs suffered losses and were forced to close their business. Once in a difficult situation, those entrepreneurs who were able to rebuild to work in the new economic conditions of restrictive measures survived. Some entrepreneurs began to master digital technologies and sell their goods using the Internet. Others switched to the production of antique products. Still others looked for buyers through popular social networks. Overcoming the economic crisis after the pandemic COVID-19 depends primarily on the activities of individual entrepreneurs in the region. It is they who quickly react and create jobs in the region, saturate markets with goods and services, and form the profitable part of the country's budget. In connection with the above, it seems relevant to conduct a statistical analysis of the activities of individual entrepreneurs in the regions of Russia, in particular, to study the dynamics of individual entrepreneurs, their structure by types of economic activities, to determine the regions with the largest and smallest number of individual entrepreneurs per 1000 population, to identify the relationship between the number of individual entrepreneurs and their revenue from the sale of goods, work.
\end{abstract}

\section{Introduction}

The number of individual entrepreneurs is an important indicator of the socio-economic development of the region. The importance of public involvement in individual entrepreneurship is explained by several circumstances. First, individual entrepreneurs solve the problem of employment by creating additional jobs in the region. Thus, they realize the social function of the region. Secondly, individual entrepreneurs satisfy the local needs of buyers who are not served by large and medium-sized businesses (economic function). Thirdly, by registering their business, entrepreneurs increase competition in the

\footnotetext{
* Corresponding author: vavangel@mail.ru
} 
industry, which forces other companies to develop, improve the quality of products or services provided, and introduce innovations into production. Fourth, it is individual entrepreneurship that helps people to unlock their creative potential, realize their dreams in business. Fifth, a class of small owners is formed who are interested in the development of their country's economy. Sixth, individual entrepreneurs are sources of economic growth in the region, working in territories of advanced development. Seventh, entrepreneurs independently make management decisions in business, plan their working day, do not report to the public for the results of their activities.

The development of individual entrepreneurship in the region is influenced by various factors. Among the constraints should be noted: the lack of effective measures to support small businesses, the imperfection of legislation in the field of small businesses, lack of resources, poor training of entrepreneurs.

Analysis of the literature showed that a large number of articles are devoted to individual entrepreneurship $[1,2,3]$. They consider the legal aspects of individual entrepreneurship, present an analysis of tax systems, consider the features of bankruptcy, the problems of individual entrepreneurship associated with high interest rates on loans, the high level of deductions for compulsory medical and pension insurance. Most of the articles are devoted to assessing the performance of individual entrepreneurs in certain regions of Russia. For example, the work of the [1] considers the activities of individual entrepreneurs in the Republic of Khakassia. The author raises the problem of obtaining systematic information on this category of subjects by cities and regions of the republic. Actual data on the business sector in the context of municipalities are formed only according to the results of a continuous survey with a frequency of every five years. Therefore, in the period between continuous observations of T.V. Sharshova, it is proposed to conduct an annual sample survey of employment of the population in the sector of individual entrepreneurs in the context of cities and districts of the republic.

The article [2] presents an assessment of the performance of individual entrepreneurs in the regions of Russia for 2018. It is shown that the average revenue per individual entrepreneur in the regions of Russia in 2018 amounted to 5.7 million rubles. per year or 475 thousand rubles. per month. In most regions, the indicator under consideration ranged from 3.9 to 7.5 million rubles.

One of the options for the development of entrepreneurship in the region is the creation of priority development territories. The [3] 's work on the example of the Far East shows that in cities where special legal regimes for entrepreneurial activity are created, the average value of differences in spatial price differentiation levels in 2014 and 2019 is less than in cities where this regime is not introduced.

With a relatively large number of scientific publications, statistical analysis of the activities of individual entrepreneurs in our country does not pay enough attention. At the same time, there are practically no publications of statistical analysis of individual entrepreneurship in the Amur Region, which is the border region of the Russian Federation.

The purpose of the study is to conduct a statistical analysis of the activities of individual entrepreneurs in the regions of Russia, in particular, to study the dynamics, their structure by types of economic activities, to implement the grouping of subjects of the Russian Federation by the number of individual entrepreneurs for 2019, to determine the dependence between the number of individual entrepreneurs and the revenue from the sale of goods, works, services, as well as the unemployment rate.

Statistical analysis tools are used as methods, in particular, dynamics indicators, structures, grouping.

The empirical data provided on the website of Rosstat, characterizing activities of SP for types of economic activity and territorial subjects of the Russian Federation of [4] formed information base of a research. For statistical analysis, such indicators as the 
number of actual individual entrepreneurs in the constituent entities of the Russian Federation, the population by region as of January 1, 2020, the amount of revenue (taking into account taxes and similar mandatory payments) from the sale of goods, products, works, services in the constituent entities of the Russian Federation, the unemployment rate of the population aged 15-72 years in the constituent entities of the Russian Federation were used.

This study is a continuation of the scientific work begun in [5], where the analysis of the number of individual entrepreneurs of the Far Eastern Federal District for 2010-2016 was performed. This work shows that for 2010-2016. the number of individual entrepreneurs in the Far Eastern Federal District has increased significantly, and the number of employees in the field of individual entrepreneurship has decreased. With the help of advance ratios, it was revealed that the growth rate of the number of individual entrepreneurs is ahead of the growth rate of the number of employees in the field of individual entrepreneurship.

\section{Major Part}

\subsection{Statistical analysis of the dynamics of individual entrepreneurship in the federal districts of the Russian Federation}

In the Russian Federation in 2019, the number of actually operating individual entrepreneurs (IE) amounted to 2738.576 thousand people. In 2019, compared to 2008, the number of individual entrepreneurs decreased slightly - by only 3377 thousand people. or $0.123 \%$. The largest decrease in the number of individual entrepreneurs in the country was observed in 2011 and 2014: by $8.64 \%$ and $11.97 \%$, respectively. Since 2015, in the Russian Federation there has been a trend of steady growth in the number of actually operating individual entrepreneurs. In 2019, compared to 2018, the number of registered individual entrepreneurs increased by 107.792 thousand people or $4.097 \%$.

Figure 1 shows the dynamics of actual individual entrepreneurs in the federal districts of the Russian Federation.

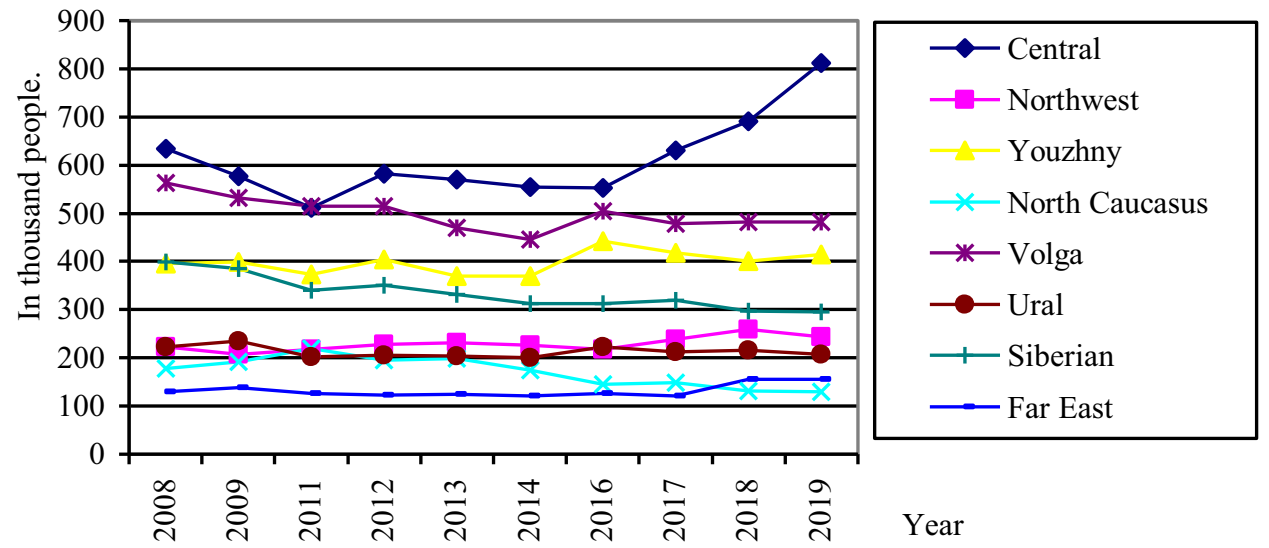

Fig. 1. Dynamics of actual individual entrepreneurs in the federal districts of the Russian Federation.

Fig. 1 shows that in half of the country's federal districts, the number of individual entrepreneurs in absolute terms has decreased over 12 years, and in the other half it has increased. So, in the North Caucasus, Volga, Ural, Siberian federal districts, the number of IE decreased, and in the Central, North-Western, South, Far Eastern federal districts increased. The highest rate of IE decline was recorded in the North Caucasus Federal 
District and amounted to $72.57 \%$, respectively, the decrease was $27.43 \%$ in relative terms. The largest growth rate of actually operating individual entrepreneurs was observed in the Central Federal District - 128.15\%. In terms of the growth rate of individual entrepreneurs for 12 years, the Far Eastern Federal District is in second place, ahead of the Northwest and Southern Federal Districts, where the growth rate was 119.75\%.

In the Far Eastern Federal District, the number of actually operating individual entrepreneurs increased from 129,337 people. in 2008, up to 154,875 people. in 2019 (by 25538 people. or 19.75\%). Although in 2019, compared to 2018, 796 individual entrepreneurs ceased to operate in the Far Eastern Federal District, or $0.51 \%$ of the total. The increase in IE in the Far Eastern Federal District is explained by a change in the territorial borders of the Far Eastern Federal District. So, in 2018, the Far Eastern Federal District included the Republic of Buryatia and the Trans-Baikal Territory. If we exclude these regions from the analysis, it turns out that the number of individual entrepreneurs in the Far Eastern Federal District in 2019 compared to 2008 decreased by 4385 people. or 3.4 $\%$.

During the period under review, among the regions of the Far Eastern Federal District, an increase in the number of individual entrepreneurs is observed in only 2 . In the Republic of Sakha (Yakutia), the number of actually operating individual entrepreneurs increased in 2019 compared to 2008 by $28.9 \%$, in the Sakhalin Region - by $5.54 \%$. In other subjects of the Far Eastern Federal District, the number of individual entrepreneurs decreased. The largest decrease is observed in the Magadan region - by $38.04 \%$ and in the Amur region by $22.63 \%$.

\subsection{Statistical analysis of the structure of individual entrepreneurs in the federal districts of the Russian Federation}

Figure 2 shows the share of each federal district in the total number of individual entrepreneurs in Russia.

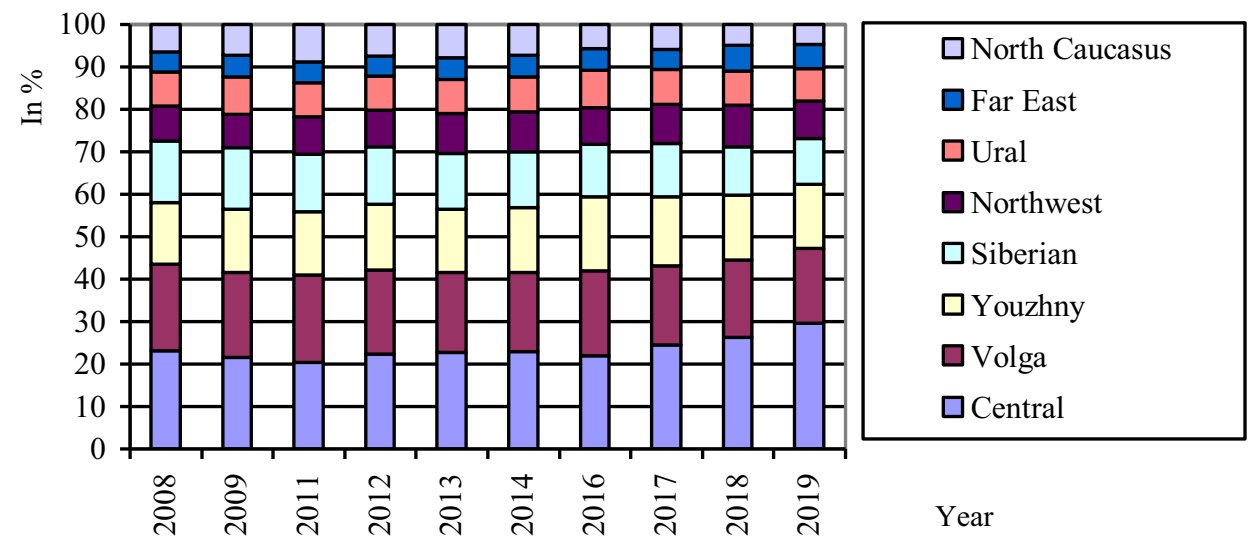

Fig. 2. Structure of actual individual entrepreneurs in the federal districts of the Russian Federation.

Fig. 2 indicates that during 2008-2019. the largest proportion of actual individual entrepreneurs was in the Central Federal District - 29.63\% in 2019. The smallest number of registered individual entrepreneurs between 2008 and 2017 was in the Far Eastern Federal District, in particular, $4.71 \%$ in 2017. In 2018, the situation changed. The Far Eastern Federal District improved its position by moving to seventh position and leaving the North Caucasus Federal District behind. In 2019, the share of individual entrepreneurs of the 
North Caucasus Federal District in the total structure of individual entrepreneurs of the country amounted to only $4.7 \%$.

\subsection{Statistical analysis of the structure of individual entrepreneurs by type of economic activity for 2017-2019}

Figure 3 shows the structure of IE by type of economic activity for 2017-2019. The diagram given in Figure 3 shows that in the regions of Russia IE operating in the field of wholesale and retail trade prevails. $41.84 \%$ of all entrepreneurs specialize in this activity for 2019.

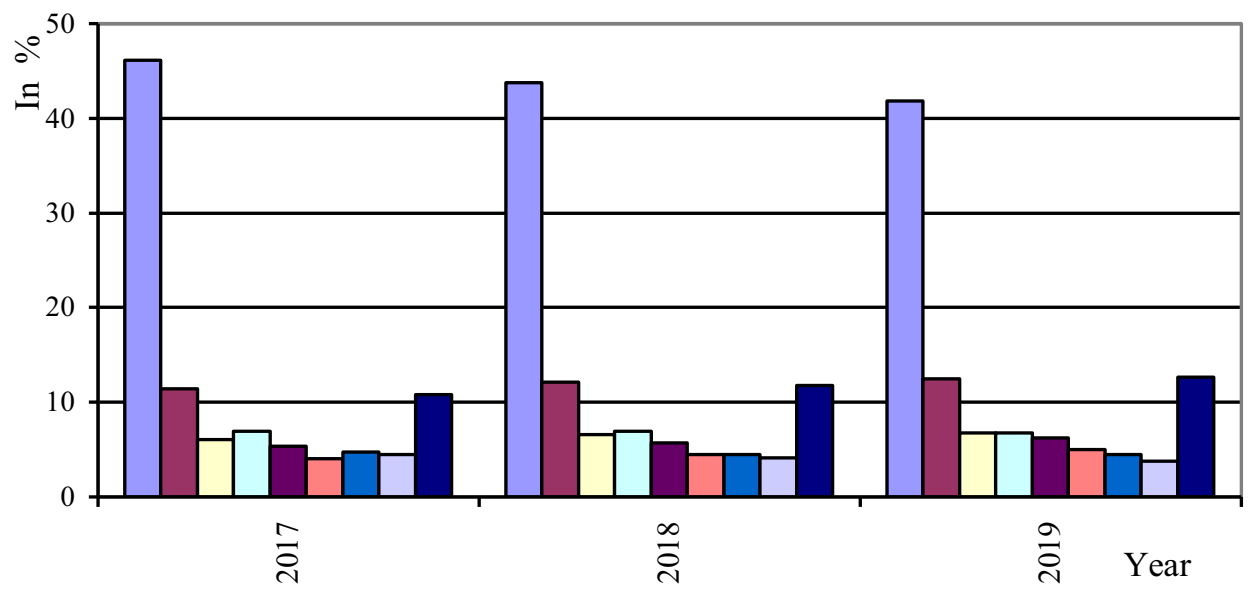

\begin{tabular}{|ll|}
\hline$\square$ Trade & $\square$ Transportation and Storage \\
$\square$ Professional, scientific, technical activities & $\square$ Provision of other services \\
$\square$ Real estate activities & $\square$ Construction \\
$\square$ Manufacturing & $\square$ Agriculture \\
$\square$ Other activities & \\
\hline
\end{tabular}

Fig. 3. Structure of IE by economic activity for 2017-2019

At the same time, in the dynamics, the share of trade in the structure of individual entrepreneurs shows a downward trend. Over the past three years, the absolute decrease in the share of trade was 4.31 percentage points. In the structure of trade, retail trade occupies the largest share, which is $82 \%$. The high share of trade entrepreneurs is explained by the structure of the economies of the regions, where the structure of gross value added is dominated by "wholesale and retail trade." Confirmation of this statement is the study of the structure of the economies of the regions, for example, presented in the work of the [6]. The work shows that in the sectoral structure of the economy of the Amur region there is a significant share of wholesale and retail trade (11.0\% in 2016). In 2004-2016, the contribution of the Wholesale and Retail Trade industry to the GRP of the Amur Region decreased slightly - by 2.3 pp - from $13.3 \%$ in 2004 to $11.0 \%$ in 2016 . On the one hand, there were practically no industrial enterprises in the region whose activities were stopped in the 1990s. On the other hand, in order to survive the crisis, many citizens engaged in entrepreneurial activities in trade, gaining the only source of income here. 
To this should be added that, trade is considered an "easy" business. The provision of trade services by entrepreneurs does not require the purchase of expensive.

In second place in the structure of IE is the share of entrepreneurs involved in the transportation and storage of goods $-12.44 \%$ for 2019 . IE, as a rule, carry out road transportation.

The negative point is that a small number of entrepreneurs are employed in manufacturing - only $4.47 \%$ for 2019 .

\subsection{Analytical grouping of regions of the Russian Federation by the number of individual entrepreneurs per 1000 population for 2019.}

To compare the regions with each other in terms of the number of individual entrepreneurs, it is necessary to lead the absolute values of the indicators to a comparable type. For this, the number of actually operating individual entrepreneurs is correlated with the population of the region. According to the data received, a grouping of regions of the Russian Federation for 2019 was carried out. The optimal number of groups for a total of 83 regions was 7 . The interval is 3.18 people. per 1000 population. The following factors were chosen as supporting factors: revenue per $1 \mathrm{IE}$ in rubles and the unemployment rate in percent. The results of the analytical grouping are shown in Table 1.

Table 1. Analytical grouping of regions of the Russian Federation by the number of actual individual entrepreneurs per 1000 population for 2019 .

\begin{tabular}{|c|c|c|c|c|c|c|c|}
\hline \multirow{2}{*}{\multicolumn{2}{|c|}{$\begin{array}{l}\text { Groups of regions } \\
\text { by number of } \\
\text { individual } \\
\text { entrepreneurs per } \\
1000 \text { population }\end{array}$}} & \multicolumn{2}{|c|}{$\begin{array}{l}\text { Number of } \\
\text { regions }\end{array}$} & \multicolumn{2}{|c|}{ Revenue for 1 IE, RUB } & \multicolumn{2}{|c|}{$\begin{array}{l}\text { Unemployment rate of the } \\
\text { population aged } 15-72 \\
\text { years, } \% \\
\end{array}$} \\
\hline & & \multirow{2}{*}{ 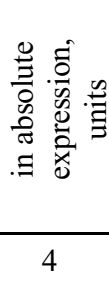 } & \multirow{2}{*}{ 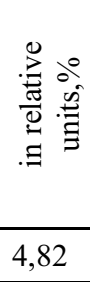 } & \multirow{2}{*}{$\begin{array}{c}\stackrel{\text { 퓽 }}{\stackrel{\Xi}{\Xi}} \\
340702,3 \\
\end{array}$} & \multirow{2}{*}{ 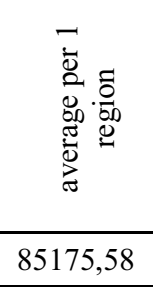 } & \multirow{2}{*}{$\begin{array}{c}\stackrel{\text { 퓽 }}{\stackrel{\Xi}{\Xi}} \\
57,3 \\
\end{array}$} & \multirow{2}{*}{ 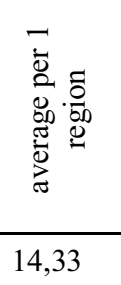 } \\
\hline 6,76 & 9,94 & & & & & & \\
\hline 9,94 & 13,13 & 4 & 4,82 & 455788,2 & 113947,1 & 31,4 & 7,85 \\
\hline 13,13 & 16,31 & 15 & 18,07 & 1511722 & 100781,5 & 86,1 & 5,74 \\
\hline 16,31 & 19,49 & 26 & 31,33 & 2784181 & 107083,9 & 140,4 & 5,40 \\
\hline 19,49 & 22,67 & 24 & 28,92 & 2673033 & 111376,4 & 106,3 & 4,43 \\
\hline 22,67 & 25,86 & 5 & 6,02 & 534287,2 & 106857,4 & 29,7 & 5,94 \\
\hline 25,86 & 29,04 & 5 & 6,02 & 865886,9 & 173177,4 & 26,4 & 5,28 \\
\hline \multicolumn{2}{|c|}{ Total } & 83 & 100 & 9165600,8 & 110428,93 & 477,6 & 5,75 \\
\hline
\end{tabular}

According to table 1, the majority of the regions of the Russian Federation, namely 26, which is $31.33 \%$ of the total, have a number of actual IE from 16.31 to 19.49 per 1000 population. In $60.24 \%$ of the regions, the number of individual entrepreneurs per 1000 population varies from 16.31 to 22.67 people. The smallest number of individual entrepreneurs per 1000 population is observed mainly in the regions of the North Caucasus Federal District, in particular, in the republics of Ingushetia (6.76), Chechen (7.47), Dagestan (8.01), as well as in the Nizhny Novgorod region (9.61). 
The largest number of individual entrepreneurs per 1000 population was noted in the Republic of Sakha (Yakutia) (26.01), in the city of federal significance Sevastopol (26.93), the Republic of Crimea (28.5), Sakhalin Region (28.83), Krasnodar Territory (29.04). The listed regions are represented from various federal districts of the Russian Federation.

Amur region is assigned to the third group of regions with the number of individual entrepreneurs from 13.13 to 16.31 people. In 2019, 15.6 individual entrepreneurs per 1000 population actually worked in the region.

A study of the dependence of the number of individual entrepreneurs and the amount of revenue (taking into account taxes and similar mandatory payments) on the sale of goods, products, works, services in the constituent entities of the Russian Federation showed that with an increase in the number of individual entrepreneurs in the region, IE revenue also grows. If in the first group for 1 region accounted for 85175.58 rubles. revenue per 1 IE, then in the seventh group - 173177.4 rubles. In the regions of the Russian Federation in 2019 , compared to 2008, IE revenue from the sale of goods, products, works, and services increased by 2 times.

The relationship between the number of PIs per capita in the region and the unemployment rate was also identified. Table 1 shows clearly that with the increase in the number of individual entrepreneurs in the region, the unemployment rate is falling. So, in the first group of regions, the unemployment rate was $14.33 \%$ per 1 region, and in the last group - 5.28\%.

\section{Conclusion}

A statistical analysis of the activities of individual entrepreneurs in the regions of the Russian Federation showed that in 2019, compared to 2008, in absolute terms, the number of actual individual entrepreneurs in the regions of Russia decreased slightly. At the same time, since 2015, in the regions of the Russian Federation there has been a trend of steady growth in the number of actually operating individual entrepreneurs.

The largest contribution to the number of individual entrepreneurs of the country is made by the regions of the Central Federal District, the smallest by the North Caucasus Federal District.

According to the analysis of the IE structure by type of economic activity, individual entrepreneurs specializing in retail trade predominate in the regions of Russia. $42 \%$ of entrepreneurs are employed in this industry.

Using the analytical grouping of regions of the Russian Federation by the number of individual entrepreneurs, regions with high and low IE values per 1000 population were identified. It is proved that with an increase in the number of individual entrepreneurs in the region, their revenue is calculated. The inverse relationship between the number of individual entrepreneurs in the region and the unemployment rate has been confirmed.

Thus, individual entrepreneurs play a large role in the socio-economic development of the region. The authorities need to constantly consider the tools of saturating industries and regions with entrepreneurs to reduce unemployment, increase budget revenues, increase the standard of living of citizens and ensure the economic security of the region. The practical significance of the statistical analysis carried out is that its results can be used by regional authorities to analyze the development of individual entrepreneurship in the region and determine targeted measures to support it. 


\section{References}

1. T.V. Sharshova. A survey on population employment in the sector of individual entrepreneurs at the municipal level, in: Voprosy statistiki. vol. 6, 2015; pp. 66-74.

2. Y.S. Pinkovetskaya. Assessment of activity indicators of individual entrepreneurs in Russia, in: Statistics and Economics. vol. 17 (1), 2020; pp. 44-53.

3. A.V. Stupnikova. Dynamics of Spatial Differentiation of Prices in the Cities of the FEFD on the Background of Development of New Institutional Regimes. Regionalistica [Regionalistics]. 2020. Vol. 7. No. 6. pp. 84-93.

4. Institutional transformation in the economy https://rosstat.gov.ru/folder/14036

5. A.V. Vasilieva. Statistical analysis of the dynamics of individual entrepreneurs of the Far Eastern Federal District for 2010-2016/Statistical analysis of the socio-economic development of the constituent entities of the Russian Federation: Materials of the 5th International Scientific and Practical Conference (March 30, 2018 )/Bryansk State University of Engineering and Technology. - Bryansk,2018. pp. 36-40

6. Vasilyeva A.V. Structural Shifts in the Economy of the Amur Region, in: Voprosy statistiki. vol. 26 (3), 2019; pp. 23-34. 